\title{
Literature and medicine
}

\author{
Introducing a new column \\ Brian Hurwitz and Neil Vickers
}

This is the first of a regular column in Clinical Medicine devoted to the interactions of literature and medicine. What do literature and medicine have to say to one another and what affinities do they share?

Medicine has always been seen as a body of esoteric knowledge that is impenetrable to the laity and weighed down with accolades by the learned. Until two or three centuries ago it was also widely suspected of doing no real good. Shakespeare could write a whole play Henry the Fourth, Part 2 - in which the surest sign that a character harbours criminal intentions is that they use the language of physic. Doctors get short shrift in Shakespeare's plays; the most honourable are those who make the smallest claims for their art, like the one who treats Lady Macbeth ('therein the patient must minister to himself'). In more than one drama, Molière used the doctor-patient relationship to teach his contemporaries a grand lesson about the nature of deception: that only someone who deceives himself will be deceived by others.

In the early 19th century, such scenarios fade as the first depictions of the 'doctor as hero' begin to appear as scientific medicine comes to be seen as more beneficial than harmful to the public. George Eliot, in Middlemarch (1871), could use the reform of the medical professions as a symbol of the wider transformation of 19th century society. Both were messy processes, full of unforeseen and adverse consequences, even for those who most favoured change. Medicine today is an object of fascination for many non-medics. Through it are refracted all kinds of public anxieties concerning the provision of healthcare, relations between the sexes and ethical concerns arising from new powers conferred by scientific progress. Hence some of the most important, as well as the most popular, fiction of our time gives a conspicuous role to medicine. The phenomenal success of Ian McEwan's Saturday (2005) demonstrates how eager the reading public is to step into the mind of a doctor as does that of House, the most watched television show on Fox TV. In Britain, Jed Mercurio's dark parable about modern healthcare Bodies (2002) has been turned into a mass-market BBC drama series.

From the medical side of the divide, literature has sometimes appeared to be as strange to physicians as medicine has appeared to the laity. What inspiration can a profession that strives to base its proceedings on science derive from fantasy? An answer of sorts is attributed to Thomas Sydenham, the so-called 'English Hippocrates'. It was reported by one of Sydenham's students that Don Quixote was the only work he would recommend when asked what students should read to help them to become good doctors. ${ }^{1}$ According to one of his biographers, Sydenham could see in Quixote an emblem of what goes wrong when men place more faith in books and received ideas than in experience and observation. ${ }^{2}$ Reading Cervantes would help deter students from tilting at windmills of their own! Writing in an age that had absorbed the lessons of Romanticism, William Osler, who numbered literature among his many fields of expertise, could be more positive - he urged medical students to embark on a wide and deep survey of world literature that would include the Old and New Testaments, Shakespeare, Montaigne, Marcus Aurelius, Cervantes and Emerson. Osler believed that medical textbooks could give students knowledge but literature and the arts would give them the self-knowledge required to enable them to become wise practitioners. ${ }^{3}$ William Gooddy, the 20th century neurologist, recommended Proust to his students, apparently on the grounds that no one had better described certain sorts of neurological disturbance 'from the inside., 4,5 Developed capacities both to notice and vividly encapsulate observations have enabled authors of the past to depict clinical problems in the lives of protagonists - physical and psychological sometimes long before their recognition and codification as medical syndromes; ${ }^{6-8}$ literary representation has helped to alert doctors (and the public) to a newly defined clinical condition ${ }^{9}$ and, on occasion, has focused medical attention on critically important features of a medical situation that previously had gone unnoticed. ${ }^{10,11}$

We hope this regular column will open up conversations about the links and synergies between these two fields of human thought, experiment and industry. It will investigate the sorts of images of doctoring found in drama, poetry, fiction, biography, electronic fora and film, and the role literature now plays in the life of working doctors. We are keen to receive contributions from readers (1,000 words or less) about works - novels, poems, plays, films, biographies or memoirs - that mean a 
great deal to them. The column will offer opportunities to explore how modern literature can help to rehabilitate interest in stigmatised 'unfashionable' problems, such as dementia, incontinence and chronic pain; in the longer term, we hope to attract contributions from sufferers and carers too. We would also be pleased to publish clinical case reports that have something of value to convey, in depictions that go beyond conventional content of clinical case reports, speaking perhaps of doctors' feelings, patient experience and doctor-patient relationships. ${ }^{12}$

We particularly hope to carry discussion of new works with medical resonances and significance. For instance, the Danish art house director Lars Von Trier recently produced two very fine satirical television dramas about a hospital in Copenhagen, Riget. (Von Trier has always been fascinated by the cinematographic power of illness and has featured a great many disabled actors in his films.) What do doctors think about the portrayal of Dr Melfi in
The Sopranos or the characterization of Henry Perowne, the ruminative neurosurgeon in Ian McEwan's Saturday? How do they feel about the maverick medical genius that is Dr Gregory House?

There are currently a large number of doctor-writers commanding the attention of the public as well as the profession, which warrant attention in these pages. Literature and medicine is a field of energetic dialogue and interaction - we would like to carry interesting short reports of research about both spheres to fuel discussion of the vital overlaps between these areas of human thought, experience and imagination.

\section{References}

1 Blackmore R. A treatise upon the small-pox. London: John Clark, 1723:xi-xii.

2 Payne JF. Thomas Sydenham. In: Oxford dictionary of national biography, 1st edn. London, 1898.

3 Osler W. Knowledge and wisdom. In: Aequanimitas. London: H K Lewis, 1904.

4 Gooddy W. Some comments on the significance of retrograde amnesia, with an analogy. Brain 1964;87:75-88.
5 Lees A. William Walton Gooddy. BMJ 2005;330:909.

www.bmj.com/cgi/content/full/330/7496/ 909-a/DC1

6 Stien R. Shakespeare on Parkinsonism. Mov Disord 2005;20:768-71.

7 Larner AJ. Did Charles Dickens describe progressive supranuclear palsy in 1857 ? Mov Disord 2002;17:823-3.

8 Schoffer KL, Sullivan JD. Charles Dickens: the man, medicine, and movement disorders. J Clin Neurosci 2006;13:898-901.

9 Cronin AJ, The Citadel. London: Victor Gollancz, 1937.

10 Robb-Smith AHT. Thallium and a pale horse. Lancet 1987;872.

11 Aronson J. Colourful metals. BMJ 2007;334:205.

12 Hurwitz B. Form and representation in clinical case reports. Lit Med 2006;25:216-40. http://muse.jhu.edu/journals/literature_an d_ medicine/v025/25.2hurwitz.pdf 